Brain Research, 96 (1975) 407-412

C) Elsevier Scientific Publishing Company, Amsterdam - Printed in The Netherlands

\title{
The homologous methylation of tRNA in rat brain
}

\author{
C. J. CUMMINS, C. E. SALAS AND O. Z. SELLINGER*
}

Laboratory of Neurochemistry, Mental Health Research Institute, University of Michigan Medical Center, Ann Arbor, Mich. 48104 (U.S.A.)

(Accepted June 11th, 1975)

Although several reports describing the properties of cerebral tRNA methyltransferases and of the regional variations in their activities with age have appeared ${ }^{4,6}$, $9,10,20,22$, the activity of these enzymes has always been measured in terms of the number of $\left[{ }^{14} \mathrm{C}\right.$-methyl] or $\left[{ }^{3} \mathrm{H}\right.$-methyl] groups transferred from appropriately labeled S-adenosyl-L-methionine onto tRNAs purified from non-neural sources $4,6,9,10,20,22$. Studies on cerebral methylation of tRNA in vivo have been few $\mathrm{w}^{7,8,21}$ and thus the specificity spectrum of the tRNA methyltransferases of neural tissue as well as the role these enzymes play in the processes of maturation and modification ${ }^{16}$ of neuronal ${ }^{1}$ and glial tRNAs is wholly unknown.

While exploring the consequences of a prolonged depletion of cerebral Sadenosyl-L-methionine ${ }^{17}$ on cerebral methylations ${ }^{18}$, we noted a significant transfer of $\left[{ }^{14} \mathrm{C}\right.$-methyl $]$ groups from S-adenosyl-L-[14C-methyl $]$ methionine onto tRNAs of the same brain extracts from which we prepared the tRNA methyltransferases, i.e., we observed homologous tRNA methylation, a reaction described only once before in a mammalian system, viz. in rat liver ${ }^{5}$. In the present communication we provide evidence that the homologous methylation of brain tRNA involves principally two positions of its guanine residues.

Male Sprague-Dawley rats were decapitated and the cerebral cortex excised and weighed. A $33 \%(\mathrm{w} / \mathrm{v})$ homogenate prepared in medium A of $\mathrm{Pegg}^{14}$ was centrifuged at $104,000 \times g$ for $60 \mathrm{~min}$ and the supernatant used directly as a source of methyltransferases. S-adenosyl-L-[14C-methyl]methionine $(58 \mathrm{mCi} / \mathrm{mmole})$ was from New England Nuclear, Boston, Mass., and E. coli B. from Schwarz-Mann, Orangeburg, N.Y. [ ${ }^{14} \mathrm{C}$-methyl] transfer was determined both by the 'rate' and the 'total extent' assays, as described by Pegg ${ }^{14}$. The rate of methylation is expressed as nmoles of $\left[{ }^{14} \mathrm{C}\right.$-methyl $] / \mathrm{mg}$ of protein $/ 30 \mathrm{~min}$, while the 'total extent' methylation is expressed as nmoles of $\left[{ }^{14} \mathrm{C}\right.$-methyl $] / \mathrm{mg}$ of protein $/ 60 \mathrm{~min}$, each being measured under appropriately optimized conditions ${ }^{15}$. Incubations were at $37{ }^{\circ} \mathrm{C}$. Endogenous methylation is defined as the methylation occurring in the absence of E. coli B. tRNA, while total methylation is defined as the methylation occurring in its presence. The

* To whom requests for reprints should be sent. 
TABLE I

THE METHYLATION ACTIVITY OF RAT BRAIN CORTEX

A: for the 'total extent' assay, each tube contained 7 nmoles of S-adenosyl-[ ${ }^{1+} \mathrm{C}$-methyl $]$ methionine, $0.15 \mu$ moles of Tris- $\mathrm{HCl}$ buffer, $\mathrm{pH} 8.6$ and about $1.1 \mathrm{mg}$ of brain cortex protein in addition to 150 $\mu \mathrm{g}$ of E. coli B. tRNA, as indicated. Incubations were at $37^{\circ} \mathrm{C}$ for $60 \mathrm{~min}$ in a total volume of 0,67 $\mathrm{ml}$. To determine the extent of $\left[{ }^{1+} \mathrm{C}\right.$-methyl] transfer, triplicate $0.25 \mathrm{ml}$ aliquots were placed on discs of Whatman No. 1 filter paper and were processed according to Pegg ${ }^{14}$. Their radioactivity was determined in a Unilux II (Searle Analytic, Des Plaines, Ill.) spectrometer. The values are the means \pm S.E.M. of 6 individual determinations in triplicate. B: for the 'rate' assay, the conditions were as in A except that only $0.15 \mathrm{mg}$ of brain cortex protein was incubated. The time of incubation was 30 min. The samples were processed as in A. The values are the means $=$ S.E.M. of 6 individual determinations in triplicate. $\mathrm{C}$ : following incubation as in $\mathrm{B}$, triplicate $0.1 \mathrm{ml}$ aliquots were withdrawn and mixed successively with $0.1 \mathrm{ml}$ of $0.8 \mathrm{~N} \mathrm{HClO}_{4}$ and $0.8 \mathrm{ml}$ of $0.2 \mathrm{~N} \mathrm{HClO}_{4}$. The samples were then processed according to Fleck and $\mathrm{Begg}^{2}$. Following the alkaline treatment $(0.4 \mathrm{ml}$ of $0.3 \mathrm{~N}$ $\mathrm{KOH}$ at $37{ }^{\circ} \mathrm{C}$ for $1 \mathrm{~h}$ ), the clear solution containing the RNA hydrolysis products was acidified and the resulting pellet was centrifuged off and washed with cold $0.2 \mathrm{~N} \mathrm{HClO}_{4}$. The washings and the original acidified supernatant were combined and their radioactivity determined. The residual pellet was suspended in $1 \mathrm{ml}$ of water and mixed with $10 \mathrm{ml}$ of PCS solubilizer (Amersham-Searle, Arlington Heights, IIl.). Its radioactivity represents that of the 'protein' fraction. See text for additional details.

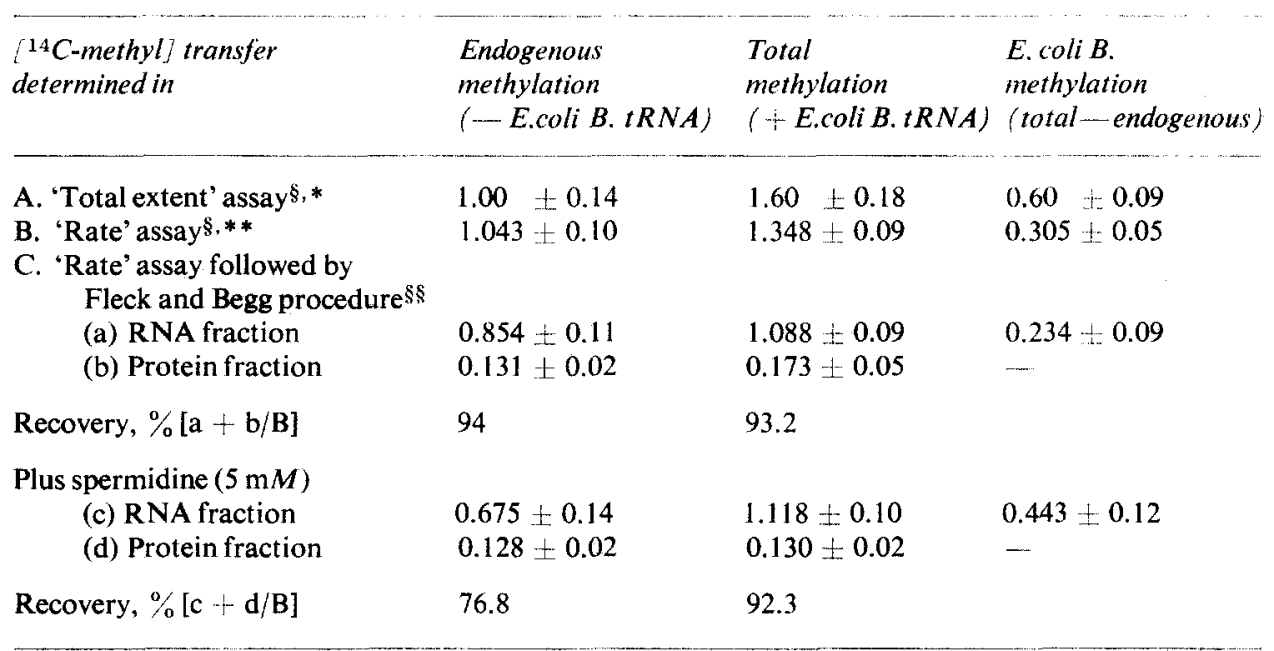

$\$$ Ref. 14.

$\S \S$ Ref. 2.

* nmoles $\left[{ }^{14} \mathrm{C}\right.$-methyl $] / \mathrm{mg}$ of protein/60 min.

** nmoles $\left[{ }^{14} \mathrm{C}\right.$-methyl $] / \mathrm{mg}$ of protein $/ 30 \mathrm{~min}$.

latter process thus comprises the sum of the methylations of endogenous $\left[{ }^{14} \mathrm{C}\right.$ methyl] acceptors (proteins and tRNAs) and of the added $E$. coli B. tRNA. The procedure of Fleck and Begg ${ }^{2}$ was used to separate the $\left[{ }^{14} \mathrm{C}\right.$-methyl $]$ products formed under both conditions of incubation into $\left[{ }^{14} \mathrm{C}\right.$-methyl $]$ protein and $\left[{ }^{14} \mathrm{C}\right.$-methyl]tRNA fractions. The latter fraction was further resolved into $\left[{ }^{14} \mathrm{C}\right.$-methyl]purine bases and $\left[{ }^{14} \mathrm{C}\right.$-methyl]pyrimidine nucleotides by means of chromatography on Dowex- $50^{3}$. Purified [ ${ }^{14} \mathrm{C}$-methyl] tRNA ${ }^{13}$ was hydrolyzed to its constituent bases in trifluoroacetic acid ${ }^{11}$ and the bases were separated by TLC $^{11}$. Autoradiograms were prepared 


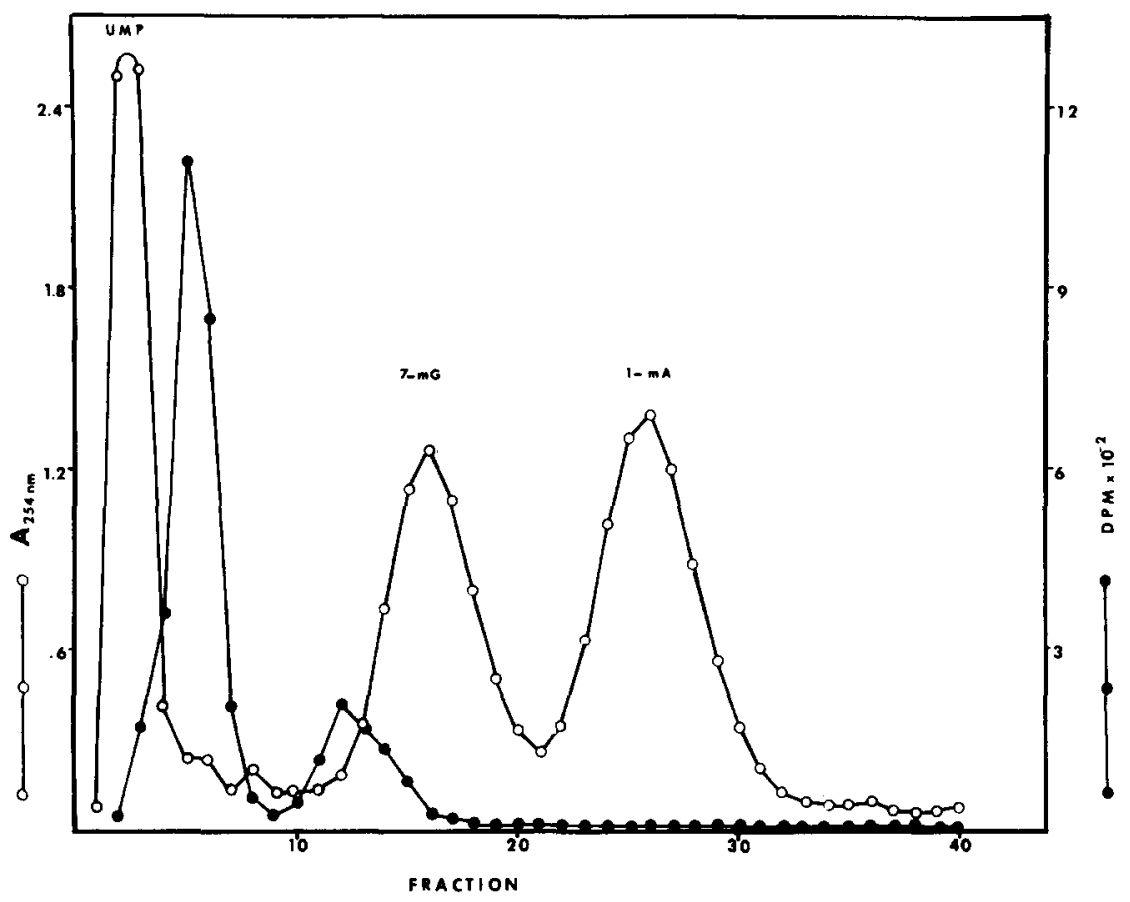

Fig. 1. lon-exchange chromatography of the $\left[{ }^{1+} \mathrm{C}\right.$-methyl] products derived by alkaline hydrolysis of the RNA fraction ${ }^{2}$. The acidified supernatant $(1 \mathrm{ml})$ resulting from the alkaline hydrolysis step ${ }^{2}$ (see legend to Table I, C) was applied to a Dowex-50 column (see text for details), equilibrated with $3.63 \mathrm{M}$ ammonium acetate buffer, $\mathrm{pH} 4.15$ and elution with the same buffer was carried out at a rate of about $1 \mathrm{ml} / \mathrm{min} ; 3.5 \mathrm{ml} /$ tube was collected. A mixture of $5^{\prime}$-uridylic acid (tubes 2-5), 7-methyl guanine (tubes 13-19) and 1-methyl adenine (tubes 22-30) was run through the column for purposes of calibration. The radioactivity in each tube was determined after mixing $2 \mathrm{ml}$ of effluent with $10 \mathrm{ml}$ of 'Scintisol Complete' (Isolab, Inc., Akron, Ohio).

on X-ray film, Type RB-254 (Eastman-Kodak, Rochester, N.Y.). Protein was determined according to Lowry et al. ${ }^{12}$. Spermidine phosphate (ICN Biochemicals, Cleveland, Ohio) was used at a concentration of $5 \mathrm{mM}$. The ${ }^{12} \mathrm{C}$-methylated purines and pyrimidines were obtained commercially (Sigma Chem. Co., St. Louis, Mo., or Cyclo Chem. Corp., Los Angeles, Calif.), except for $\mathrm{N}_{2}^{2}$-dimethyl guanine, which was a generous gift of Dr. M. Klagsbrun, Harvard Medical School, Cambridge, Mass.

The overall capacity of tRNA methyltransferases from rat cerebral cortex to transfer [ ${ }^{14} \mathrm{C}$-methyl] groups to endogenous acceptors was determined by comparing this process in the presence and absence of added E. coli B. tRNA. The results (Table I) show that approximately $60 \%$ of the transfer measured in the 'total extent' mode ${ }^{15}$ was onto endogenous acceptors and that this proportion was increased to about $77 \%$ when the 'rate' assay was applied ${ }^{15}$. A quantitative separation of the $\left[{ }^{14} \mathrm{C}\right.$ methyl] products ${ }^{2}$ (Table $I$, rows $C$, a and $C, b$ ) revealed more than $85 \%$ of the recovered radioactivity in the RNA fraction, irrespective of the presence of $E$. coli $\mathrm{B}$. tRNA. Furthermore, the data also show that over $93 \%$ of the radioactivity was 


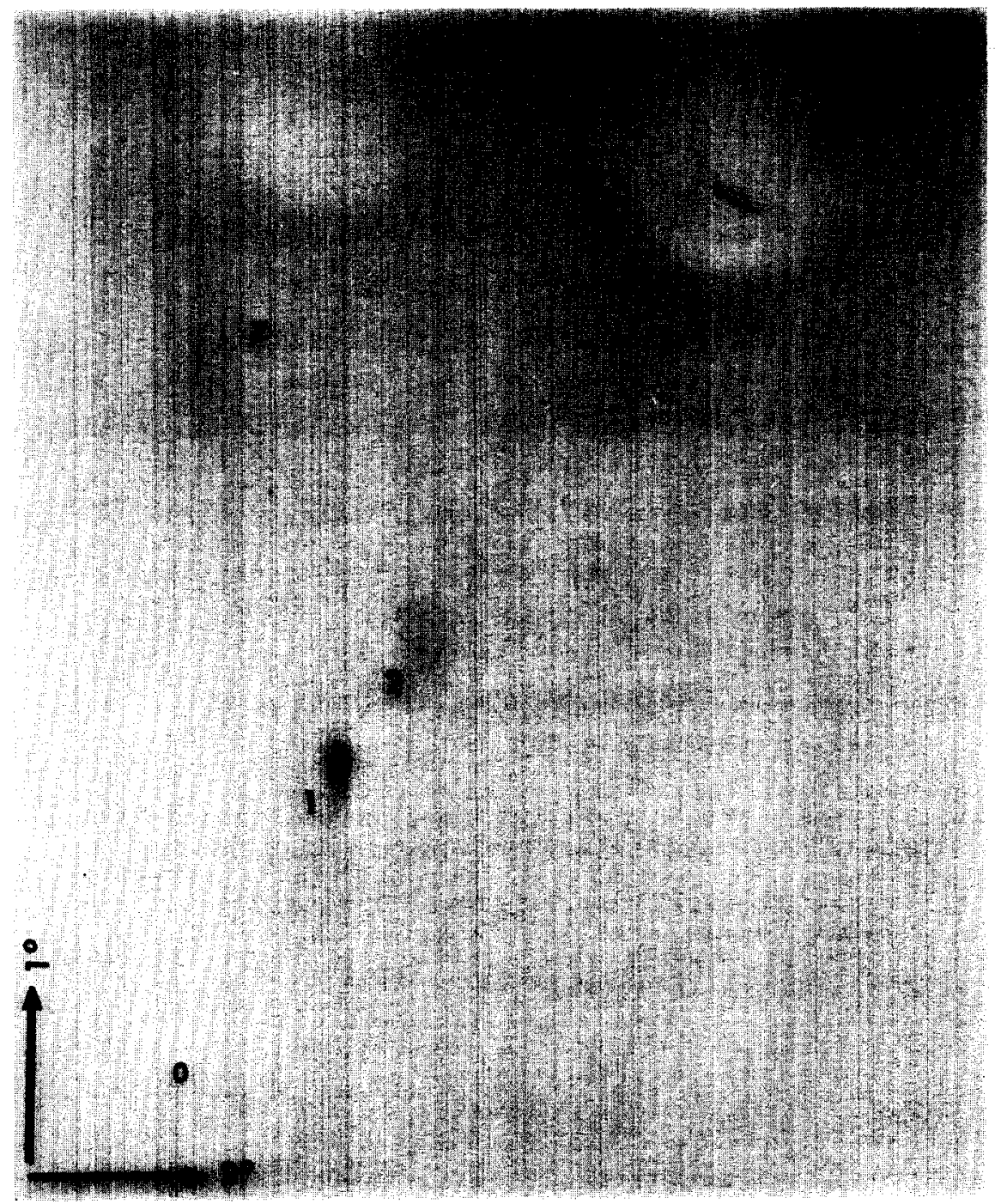

Fig. 2. Bi-dimensional thin-layer chromatography of $\left[{ }^{14} \mathrm{C}\right.$-methyl]tRNA bases: autoradiogram of the $\mathrm{CF}_{3} \mathrm{COOH}$ hydrolysate of $\left[{ }^{1 /} \mathrm{C}\right.$-methyl]tRNA formed in vitro by 3 -day-old brain tRNA methyltransferases. The hydrolysis of the purified $\left[{ }^{14} \mathrm{C}\right.$-methyl]tRNA ${ }^{13}$ was according to Klagsbrun ${ }^{11}$. The $\left[{ }^{14} \mathrm{C}\right.$-methyl] bases were separated in methanol-water-conc. $\mathrm{HCl}(70: 10: 20)$ in the first direction and $n$-butanol-glacial acetic acid-water $(68: 17: 17)$ in the second direction. The front of the solvents was allowed to rise to $14 \mathrm{~cm}$. The numerals designate the following: 0 , origin; 1 , (1-methyl guanine + 7-methyl guanine): 2, $\mathrm{N}^{2}$-methyl guanine: and 7, unidentified.

recovered by the Fleck and Begg ${ }^{2}$ procedure. In separate experiments (C. E. Salas and O.Z. Sellinger, unpublished observations) we could show that the $\left[{ }^{14} \mathrm{C}\right]$ protein fraction was insensitive to the action of RNAse-free DNAse (Worthington Biochemical Corp., Freehold, N.J.) and thus contained no ${ }^{14} \mathrm{C}$-methyl-labeled DNA. Spermidine stimulated the methylation of $E$. coli $\mathrm{B}$. tRNA by about $85 \%$, as indicated by comparing values in rows $\mathrm{C}, \mathrm{c}$ and $\mathrm{C}, \mathrm{a}$ of the (total, endogenous) column (Table I) while, 
conversely, this polyamine appeared to inhibit the methylation of endogenous tRNA by about $20 \%$. A more comprehensive analysis of the effects of age on the pattern of homologous and heterologous methylation of tRNA in rat brain cortex is presented elsewhere ${ }^{15}$. When the alkaline hydrolysate ${ }^{2}$ containing $\left[{ }^{14} \mathrm{C}\right.$-methyl]tRNA breakdown products formed by endogenous methylation of 3-day-old cerebral cortex tRNA was acidified and eluted off a Dowex-50W-X8 (200-400 mesh) column ( $1 \mathrm{~cm}$ $\times 10 \mathrm{~cm})^{3}$, the radioactivity profile (Fig. 1) indicated the definite presence of $\left[{ }^{14} \mathrm{C}\right.$ methyl]guanines ${ }^{3}$ (fractions $11-15$ ), in addition to large amounts of radioactive material eluting between the uracil and cytidine nucleotides (tubes 2-8, Fig. 1; cf. also Fig. 1 of ref. 3). Additional proof of the formation of $\left[{ }^{14} \mathrm{C}\right.$-methyl $]$ guanines during endogenous methylation is provided by the results of the TLC of a trifluoroacetic acid hydrolysate (Fig. 2) which shows two radioactive spots, identified as $\mathrm{N}^{2}$ methyl guanine and $(1+7)$-methyl guanine.

Simon et al. ${ }^{20}$ observed that rabbit liver $t R N A$ is 10 times more effective as a substrate for rat brain tRNA methyltransferases than is homologous brain tRNA and 3-4 and 4-5 times less effective than either $E$. coli B. or $E$. coli K12 tRNA. These workers also showed that rat brain contains 'more than one methylating activity' and that cerebral methylases are about 7 times more active in fetal than in adult rat brain. More recently, Johnson et al. ${ }^{6}$ compared tRNA methyltransferases in neonatal and adult mouse brain and noted significant methylation of $E$. coli tRNA but little, if any, homologous tRNA methylation. These workers stated that all of the methylation observed in the absence of $E$. coli tRNA was 'presumably the result of protein methylation', even though they failed to examine the nature of the [ ${ }^{14} \mathrm{C}$-methyl] products so produced. Our results do not support the conclusion of Johnson et al. ${ }^{\mathbf{6}}$, inasmuch as they demonstrate that, on the contrary, a sizable portion of the "endogenous methylation' in rat brain cortex involves homologous tRNA. These findings supplement the recent report by Jank and Gross ${ }^{5}$, who found that homologous tRNA methylation in adult rat liver involves principally the transfer of $\left[{ }^{4} \mathrm{C}\right.$-methyl] groups to cytidine and adenine residues to form 5-methylcytosine and 1-methyladenine. As shown in Fig. 2, tRNA methyltransferases from immature rat brain cortex introduce $\left[{ }^{14} \mathrm{C}\right.$-methyl] groups principally on brain tRNA guanine residues, thus forming tRNAs containing $\mathrm{N}^{2}$ - and $(1+7)$-[14 $\mathrm{C}$-methyl $]$ guanines. Further work is in progress to delineate more fully the patterns of homologous tRNA methylation in brain as a function of age and cell type and of the role of spermidine in this process. The possibility that the observed results are not entirely the reflection of homologous tRNA methylation, but rather of a heterocellular process, whereby neuronal ${ }^{19}$ tRNAs are methylated by glial tRNA methyltransferases and glial tRNAs by neuronal tRNA methyltransferases, will also be explored.

This research was supported by the United States Public Health Service, Grant NS-06294. CJC is a pre-doctoral trainee, NIMH 013034.

1 Azcurra, J. M., Sellinger, O. Z., and Carrasco, A. E., In vivo labeling of cytoplasmic RnA in neurons of the immature brain cortex, Brain Research, 86 (1975) 144-149. 
2 FLECK, A., AND BEGG, D., The estimation of ribonucleic acid using ultraviolet absorption measurements, Biochim. biophys. Acta (Amst.), 108 (1965) 333-339.

3 GANTT, R., AND JULiAN, B., A rapid column chromatographic procedure for the assay of RNA methyltransferases, Anal. Biochem., 54 (1973) 283-285.

4 GuRoff, G., AND Brodskx, M., Enzymes of nucleic acid metabolism in the brains of young and adult rats, $J$. Neurochem., 18 (1971) 2077-2084.

5 JANK, P., AND Gross, H. J., Methyl-deficient mammalian transfer RNA. II. Homologous methylation in vitro of liver tRNA from normal and ethionine-fed rats: ethionine effect on 5-methylcytidine synthesis in vivo, Nucleic Acids Res., 1 (1974) 1259-1267.

6 Johnson, T. C., Mathews, R. A., AND ChOU, L., tRNA methyltransferase activity in neonatal and mature mammalian neural tissue, $J$. Neurochem., 23 (1974) 489-495.

7 JUDES, C., AND JACOB, M., Compartmentation of the S-adenosylmethionine pool in developing chick embryo cerebral hemispheres, as demonstrated by a fingerprint study of 18S-ribosomal RNA, FEBS Letters, 27 (1972) 289-292.

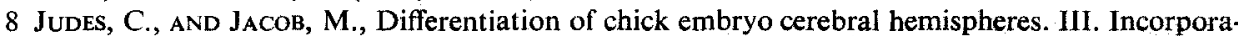
tion of [ ${ }^{3} \mathrm{H}$-methyl]methionine into 29S, 18S and 4S RNAs, Brain Research, 52 (1973) 333-344.

9 KAPLAN, B. B., RIEDESEl, W. M., AND SiRLIN, J, L., Effect of behavioural training on brain transfer RNA methylases, $J$. Neurochem., 22 (1974) 177-179.

10 KAYE, A. M., AND LeBOY, P. S., Methylation of RNA by mouse organs and tumors: ionic stimulation in vitro, Biochim. biophys. Acta (Amst.), 157 (1968) 289-302.

11 Klagsbrun, M., The contrast between the methylation of transfer ribonucleic acid in vivo and in vitro by normal and SV40 transformed 3T3 cells, J. biol. Chem., 247 (1972) 7443-7451.

12 Lowry, O. H., Rosebrough, N. J., Farr, A. L., and Randall, R. M., Protein measurement with the Folin phenol reagent, J. biol. Chem., 193 (1951) 265-275.

13 Muramatsu, M., and Funisawa, T., Methylation of ribosomal RNA precursor and tRNA in rat liver, Biochim. biophys. Acta (Amst.), 157 (1968) 476-492.

14 PeGG, A. E., The effects of diamines and polyamines on enzymic methylation of nucleic acid, Biochim. biophys. Acta (Amst.), 232 (1971) 630-642.

15 Salas, C. E., AND Sellinger, O. Z., Patterns of homologous methylation of tRNA in developing rat brain, submitted for publication.

16 Schaefer, K. P., ANd Soell, D., New aspects in tRNA biosynthesis, Biochimie, 56 (1974) $795-$ 804.

17 Schatz, R. A., and Sellinger, O. Z., Effect of methionine and methionine sulphoximine on rat brain S-adenosyl methionine levels, J. Neurochem., 24 (1975) 63-66.

18 SChatz, R. A., ANd Sellinger, O. Z., The elevation of cerebral histamine-N- and catechol-Omethyl transferase activities by L-methionine-dl-sulfoximine, $J$. Neurochem., 25 (1975) 73-78.

19 Sellinger, O. Z., Aczurra, J. M., Johnson, D. E., Ohlsson, W. G., and Lodin, Z., Independence of protein synthesis and drug uptake in nerve cell bodies and glial cells isolated by a new technique, Nature New Biol., 230 (1971) 253-256.

20 Simon, L. N., Glasky, A. J., AND REJAL, T. H., Enzymes in the central nervous system: tRNA methylase, Biochim. biophys. Acta (Amst.), 142 (1967) 99-104.

21 Sunde, D., McKelvy, J., ANd SAChS, H., Studies on RNA methylation and dissociation between RNA and protein biosynthesis in neural lobes of dehydrated rats, Brain Research, 47 (1972) 237-253.

22 SwiateK, K. R., Streeter, D. G., and Simon, L. N., Transfer ribonucleic acid methylase activity in the developing pig brain, Biochemistry, 10 (1971) 2563-2567. 